\title{
Article
}

\section{Can higher education reduce the negative consequences of police occupational culture amongst new recruits?}

Cox, Carol and Kirby, Stuart

Available at http://clok.uclan.ac.uk/18267/

Cox, Carol and Kirby, Stuart ORCID: 0000-0002-3049-1248 (2018) Can higher education reduce the negative consequences of police occupational culture amongst new recruits? Policing: An International Journal of Police Strategies \& Management, 41 (5). pp. 550-562. ISSN 1363-951X

It is advisable to refer to the publisher's version if you intend to cite from the work. http://dx.doi.org/10.1108/PIJPSM-10-2016-0154

For more information about UCLan's research in this area go to http://www.uclan.ac.uk/researchgroups/ and search for < name of research Group>.

For information about Research generally at UCLan please go to http://www.uclan.ac.uk/research/

All outputs in CLoK are protected by Intellectual Property Rights law, including Copyright law. Copyright, IPR and Moral Rights for the works on this site are retained by the individual authors and/or other copyright owners. Terms and conditions for use of this material are defined in the policies page.

\section{CLoK}

Central Lancashire online Knowledge www.clok.uclan.ac.uk

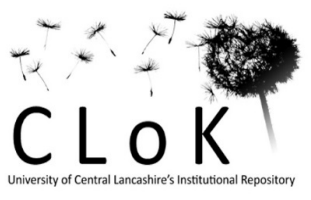




\section{ABSTRACT}

Purpose

There is considerable evidence to illustrate police occupational culture can negatively influence service delivery and organizational reform. To counteract this, and to improve professionalism, the Police services of England \& Wales will become a graduate profession from 2020, although little empirical evidence exists as to what impact this will have. This study examines the implications of a police degree course on its students.

\section{Design/Methodology}

Initially a survey was conducted with 383 University students studying for Criminal Justice related undergraduate degrees in a UK University. This indicated Police Foundation degree students $(\mathrm{N}=84)$, identified themselves as being different, and behaving differently, to other University students. To explore the reasons for this, four focus groups were conducted with this cohort, during their two-year degree programme.

\section{Findings}

The study found that the Police Foundation Degree students quickly assimilated a police identity, which affected their attitudes and behavior. The process led to a strengthening of ties within their own student group, at the expense of wider student socialization.

\section{Originality/Value}

The study provides new findings in relation to undergraduate students who undertake a University based degree programme, tailored to a future police career. The results have implications for both police policy makers and those in Higher Education as it highlights the strength of police occupational culture and the implications for the design of future police related degree programmes. 


\section{INTRODUCTION}

With the emergence of the 'new police' in the early $19^{\text {th }}$ Century, public consent became integral to effective police work, resulting in police leaders emphasizing the need for professionalism. Indeed, Rowan and Maine (the original commissioners of the Metropolitan Police), informed their staff that those who did not show high standards of civility would be dismissed (Reith, 1956:142). Records show that their expectations were often unmet with only 562 of the original 2,800 constables remaining by 1834 , due to dismissals for incivility and drunkenness (Elmsley, 2008). Since this time, politicians, the media and the wider public have continually highlighted police failings, which have generated a plethora of new legislation, inquiries and oversight mechanisms. However, as problems continually surface, the fundamental question remains as to how police professionalism can be embedded within the service.

The training and education of police officers is much-debated topic across the world and closely aligned to professionalism. Jaschke \& Neidhart (2007) argue lawyers, teachers, doctors and the clergy all experienced academic insight to prepare themselves for practical professions, and so should the Police. Similarly, Tilley \& Laycock (2016) reason the police should draw a professional parallel with engineers, whose academic background facilitates an evidence based method of trial and error, allowing them to become more proficient. These debates are generating research, with a longitudinal study on police recruitment, education, and careers (RECPOL) currently being conducted across seven European countries (Bjorgo, 2016). Emerging from this backdrop, the College of Policing (2016) announced that from 2020 policing within England and Wales will become a graduate profession. As such, specific UK Universities will provide pre-join degrees at level 6 (bachelors honours degree). The argument is that better educated officers will exhibit less prejudice and provide more objective and reflective decision making. This logic is endorsed by the UK government who have long championed higher education (H.E.) within policing, saying, "We acknowledge the benefits which a more academic approach could bring to the delivery of police learning and training.... expose officers to a wider cross-section of the community and weaken the negative elements of the occupational culture" (Home Office 1999:79). However, the view that police officers should all be graduates has divided opinion. Whilst some argue policing is a profession and should be represented by suitably qualified staff, others argue police agencies should mirror general society (most of which are not graduates). Ironically, in an age when evidence based policing is championed, the benefits of future recruits studying at University has not been fully explored. This study will examine arguments surrounding the introduction of higher level education for police recruits, specifically examining the experiences and opinions of students completing a foundation degree in policing.

\section{LITERATURE REVIEW}


Police officers have often been differentiated from employees in other organizations as the level of discretion increases as it moves down the hierarchy (Wilson, 1968:7) This discretion is unavoidable for two reasons. First, as police agencies face escalating demand with finite resources, individual officers are constantly making decisions about the level and scope of intervention. Secondly, as incidents are often diverse and nuanced they rely on judgement rather than a standard operating procedure.

Occupational culture is a subject of international academic interest and has long been linked to the use of discretion (Banton, 1964; Reiner, 2000; Punch, 1979; Fielding, 2002). Although studies consistently indicate recruits want to "make a difference" and 'help' people (Chan, 2001), this attitude changes negatively over time with real police work identified as tackling crime, and the social service side (assisting the public) viewed as an 'unwelcome distraction' (Reiner, 2000; Loftus, 2009). Although some studies highlight the positive aspects of occupational culture (Waddington, 1999), most commentators list its negative consequences (Paoline, 2003), a finding recognized both internationally and by the Police themselves (Kiely and Peek, 2002). Officers are said to become cynical, authoritarian, hardened, conservative, loyal, secretive, suspicious and isolated (Butler \& Cochrane, 1977; Worden, 1990). This can lead to aberrant behavior, ranging from incivility to corruption, leading to reductions in public satisfaction and trust as well as blocking wider organizational reform (Alcott, 2012).

The causal factors which lead to occupational culture are contested and explained along a continuum of individual and organizational considerations. Some commentators argue individuals with specific characteristics are attracted to the role (Colman \& Gorman, 1982), whilst others argue the selection procedure values and filters specific characteristics (TwerdksyGlasner, 2005). Conversely Maghan (1988) discussing anticipated socialization, argues many factors affect the recruits mindset, including their ethnicity, culture, past experience, the media and their future understanding of the role. Whatever occurs prior to joining, once recruited the Police Training School is often cited as a crucial element of socialization, where new recruits are inducted with war stories and myths, before being further indoctrinated when they hit the streets (Van Maanen, 1978; Chan, 1996). As Conlon (2004:9) states, "The day the new recruit walks through the door of the police academy, he leaves society behind to enter a profession that does more than give him a job, it defines who he is". Gaining trust from their colleagues is also viewed as an important element in their ability to 'fit in' (Cashmore, 2002). Whatever its causality, occupational culture appears resilient to the mechanisms that attempt to remove it (Martins \& Terblanche, 2003; Graef 2012), with numerous international examples of police racism, prejudice, incivility and corruption (Mclaughlin, 2007:42). Commentators are increasingly realizing police culture is dynamic and diverse (Cockroft, 2015), with individuals who resist its influence requiring more support (Chan, 1996:121). 
There is a long held view that education can assist in resisting negative occupational culture. Europe has different models of police education, Scandinavian Countries (Denmark, Sweden, Norway,) require upper secondary education as admission criteria, and generally provide academically oriented police education (Fekjaer, 2014). Conversely, the UK requires no formal qualification with recruits undergoing short vocational training (Moeburg \& Pettersson, 2016). Elsewhere, individual countries (for example Germany, the Netherlands, Hungary and the Czech Republic) have seen the establishment of Police Academies / Universities, providing HE for serving officers, predominantly senior leaders (Frevel, 2015). In Australia and the USA, police agencies have generally remained in control of standards and core academy training, with officers attending the university for wider tuition.

In the UK a number of factors have promoted the formal introduction of bachelor degrees. First, there is consistent stakeholder clamor for a more professional service utilizing better educated police students/ officers (Neyroud Report, 2011; Winsor, 2011; 2012), supported by the recently formed College of Policing in 2012. Second, a period of forced austerity has underlined the economic benefits of recruits being educated at their own cost, resulting in various police related degrees offered by UK Universities (Hallenberg, 2012). These undergraduate programmes vary on: subject matter; methods and modes of teaching; level of University integration; and the requirement to become a Special Constables during the programme (volunteers with full police powers).

The evidence to support the contention that HE can "weaken the police culture" (Home Office,1999: 79) is limited (Heslop, 2009; Dominey \& Hill, 2010), and some skepticism appears warranted. Christie et al. (1996) found a University 'pre-service semester' of Australian police recruits made a minor impact on attitudes, although Wood (1997: 276) argued one semester was insufficient to allow University socialization. Likewise, earlier studies had found no evidence that higher educated officers were any more likely to show more professionalism or be resistant to police subculture (Crank,1990), with these efforts thought to be insufficient to generate culture change (Dominey \& Hill, 2010:10). Worden (1990) and Dalley (1975) found regardless of education, police officers showed greater authoritarianism, rigidness and conservatism than other individuals.

Other commentators also reported some wider issues. In a comparative study Fekjaer (2014), found Norwegian police recruits (whose police education culminates in a formal degree) attracted students with more highly educated parents, than Swedish recruits. Whilst recruits showed no significant difference in their attitude to policing, this finding is of concern if there is a desire to recruit a representative service. Further, Heslop (2011) found police recruits undertaking a foundation degree at a British University did not feel they were viewed as 'real students', feeling both physically and psychologically isolated. They also found themselves in conflict with the lecturers, who they stated were 'patronising' 'condescending', even displaying an 'anti-police attitude (ibid: 305). Further, even though the recruits had operational 
experience, their insights were dismissed as they challenged the academic stance of their lecturers. Police officers distrust of academics and their perceived irrelevance of its value has been highlighted by others (Jaschke \& Neidhardt, 2007).

\section{METHODOLOGY}

This study took a mixed methods approach. Whilst quantitative approaches can measure numerically what is happening, qualitative approaches are more adept at answering why it is happening, by concentrating on the individual's subjective view of the world (Sarantakos, 2005). The first stage therefore used a quantitative approach by administering a general questionnaire to students ( $\mathrm{N}=383$ ), enrolled in a variety of Criminal Justice related degrees at a University campus, situated in the north of England. These students were enrolled in several honours degrees, including: Law ( $N=94)$, Criminology ( $N=93)$, Police and Criminal Investigation $(\mathrm{N}=65)$, Law and Criminology $(\mathrm{N}=47)$. A group were also enrolled in a Foundation Degree in Policing Degree $(\mathrm{N}=84)$. The data was inputted into SPSS (a statistical software package) and analysed using the chi square test.

As will be reported the numerical findings from this questionnaire prompted the next stage of the methodology. This involved a qualitative study, which concentrated on students registered on a two-year Foundation Degree course in Policing (FDP). Specifically, this involved a series of four focus groups held over three time periods. For the benefit of clarity, it should be highlighted that honours degrees and foundation degrees vary on a number of aspects. Honours degrees are generally conducted over a period of three years (full time) and students will have a number of optional modules to choose from, which are often attended by students from other degree programmes. In contrast the foundation degree is a two year programme, with each of the 12 modules being compulsory and available only to the police students (there are no joint lectures with other students). The FDP staff are also dedicated to that degree programme and consist of both academically qualified ex police officers and serving police officers. Students enroll in the same way they would for any academic undergraduate degree and have the opportunity to become Special Constables (volunteer police officers with full sworn powers). Those students who pass the selection process to become Special Constables, follow an operational policing module, and are tutored by serving police officers (therefore leave the university for one module). Those students who do not pass the Special Constable Recruitment process follow a 'pathway' module and remain at the university. The focus groups stages were:

Focus Group 1: These were in the seventh month of their two year programme, with no university arranged police contact yet taking place $(\mathrm{N}=12)$. 
Focus Group 2 \& 3: These were in the second year of study, with approximately half of cohort involved as Special Constables. The subjects were split into two groups due to the numbers involved ( $\mathrm{N}=14$ \& 12).

Focus Group 4: These students were close to the end of their degree programme, with approximately half having completed their 10 week police secondment under the tutelage of a serving police officer $(\mathrm{N}=14)$.

The facilitator for the focus groups, although not leading the FDP, was a member of University staff and the process was conducted in line with good practice to minimize interviewer bias and to improve honest engagement from the practitioners. All participants remained anonymous, with focus groups lasting approximately one-hour duration. The audio recordings were transcribed and a thematic analysis was conducted to highlight frequently recurring issues.

\section{RESULTS}

The initial analysis was completed on the undergraduate students studying a diversity of Criminal Justice related degrees $(\mathrm{N}=383)$. The survey asked a variety of questions in relation to how the students viewed themselves on the course in relation to students from other courses. These students shared a high level of similarities across demographic variables, such as gender and ethnicity. However, $48 \%$ of the Criminal Justice students described themselves as different to other students, and whilst $39 \%$ of this total stated this was because (as individuals) they were all different, a further $30 \%$ of the sample reported it was because they were police students. On closer inspection students on the Foundation degree course in Policing (FDP), were more likely to describe themselves as different, compared with students from other degree programmes (75\% compared with 40\%); $x 2=25.12, d f=1, p<0.001$ ). Indeed $61 \%$ of the FDP students reported feeling they had to behave differently compared to $39 \%$ of other Criminal Justice students; $x 2=100.99, \mathrm{df}=1, \mathrm{p}<0.001$ ).

To establish whether this finding was unusual, an identical questionnaire was delivered to a similar cohort of University FDP students, based in the South of England ( $N=37)$. The results mirrored the earlier findings. These FDP students also reported feeling different to other undergraduate students (76\%), and more likely to behave differently (90\%). Across both locations, the reason given for behaving differently from other students was because they felt they had more responsibility due to their subject choice (Northern University 46\%, Southern University 43\%).

This initial finding was pursued with four focus groups of the northern based FDP students held 
across three time periods. A subsequent thematic analysis of the transcribed interviews, generated four issues. These were: identity and behavior; the influence of the lecturers and their teaching; the student's opinion of the public; and finally police organizational culture and 'fitting in'. These will now be explored in more detail.

\section{Theme 1: Identity and behaviour}

A clear and consistent finding was the vast majority of students saw their decision to enroll on the FDP made a significant difference in the way they viewed their identity, which in turn affected their behavior. Participants, from the first focus group, explained they felt half student, half police officer, as one said,

"I think it is different from being on a normal degree where you come in for 6 hours a week and [commit to] a timetable, I do not think we really have that. You have to be more professional." (Student 11, FG1)

Another student explained that this was partly because University staff would eventually provide them with a reference to accompany any police application they submitted. This meant inappropriate behavior, witnessed by University staff, could affect their later police recruitment.

"I have adopted a start as you mean to go on; be professional now. More focused on what you are doing." (Student 2, Focus Group 1).

The students explained the FDP symbolized a long-term commitment, which they hoped would provide a lifetime career in policing. As such, many thought that professionalism from the outset was key to success. However, the impact of this ambiguous identity (between student and police officer) immediately generated conflicts of interest. They explained their concerns when invited to events or venues where illegal behavior could emerge (i.e. attendance at parties where drugs may be consumed, or public protests that had the potential to become violent). Students added that prior to joining University they were apathetic to inappropriate behavior; now having committed themselves to a future in policing they felt an obligation to challenge it. This meant they were more likely to distance themselves from sensitive situations, whilst fellow students were unlikely to invite them to potentially problematic events for similar reasons. As one explained,

"Once we got to the course there was a party and the lad is known for taking drugs, and we were not invited but all our other friends were". (Student 1, FG1). 
Indeed, most focus group participants indicated they would not disclose the subject of their undergraduate course as they thought they would be treated differently by others (both students and at places of part time work). The change in behavior affected numerous elements of their life, especially in relation to social media. The students reported their lecturers advised them to choose social media friends carefully and post appropriate content. One example was described as follows,

"In September with the basketball team we had the initiation ceremony, and we got into trouble for it and all of the pictures went on Facebook. I had to tell the captain of the team to get the photos off Facebook, as it could have got me into trouble, as you are not allowed to do initiations anymore." (Student 11, FG2)

Tangible examples of the need for more constraint and consideration of their actions became increasingly apparent as the cohort developed over time. Those who became Special Constables increasingly viewed themselves as police officers, rather than students, and they socialized within their cohort, rather than with other students.

"My life style has completely changed, so no I don't mix with other students." (Student 9, FG4).

"They become a second family, that's what I called them. I would stay at my tutor's house [Tutor Constable during placement training] and look after his dog, things like that. Nights out with the team. It helps things you deal with death, bodies... with the team you can get yourself back to normality." (Student 8, FG4)

"The people on my team, they have said to me if you do get into the police you will find the more time you are in it you will lose the friends you have, just because of work commitments and things like that and you will start socialising with police officers. So you have to be a similar type of person to hang around with the police." (Student 4, FG2)

\section{Theme 2: The influence of lecturers and their teaching}

As was previously disclosed the lecturers on the FDP are either academically qualified ex-police officers or serving police officers (seconded from the local Constabulary). Participants from all the focus groups revealed that they were clearly influenced by the lecturers, making reference to their inherent authority and experience in policing. Anecdotes were specifically highlighted as an important aspect of the learning, as these quotes explain,

"Extra respect given to the lecturers from us due to their experience." (Student 6, FG1) 
"It makes it seem a little bit more real, I always thought the lecturer just chatting to you; he sometimes does seem like the Superintendent and you really don't want to say a word out of line. You all seem to have this sort of air of authority that we conform to." (Student 7, FG3)

All stated the importance of operational examples and anecdotes in understanding and assisting how to utilize legislation and procedure, viewing these as more important than policy or guidelines.

"Like when you go to a job that is the first thing that comes back to you, and if it's similar to what you have done, you just think what did they do, and you then adapt it." (Student 7, FG2)

The students indicated that the fact this was a police related course, and that the lecturers had experience of policing, were both critical issues in differentiating this degree programme from others. Most focus group participants indicated they spent more time at the university studying and attending lectures than students on other courses. They thought the lecturers displayed higher standards in terms of work ethic and behavior. This, coupled with their desire to become police officers, all played a part in them believing they were different from other students and needed to behave differently. However, the lecturers influence only went so far, and their perspective changed when undertaking operational training. Students explained the operational police officers would cut corners, and teach them to be more assertive, as the following quote shows,

"I think we are taught the wrong way, at Uni. We are told to be polite, always can't upset people and when I went on the streets, I was getting all of this grief and not saying anything and I thought that was what I had to do. My [operational] tutor said, why are you not saying anything back? And I said I have to be polite. Well try and give it back... and I said well if I do I will say some harsh things and he said yeah ok try it. So I did, I was authoritive and gave it back, just listen, wind your neck in this is going to happen if you do that.... and it works. You get used to your own voice really." (Student 4, FG4)

Theme 3: The student's opinion of the public

A further theme to emerge was the view students had in relation to certain sections of the public. Even the first focus group, seven months into their course started to highlight these issues.

"The amount of rights that you need to give these people (the public) and the fact that you have to make them like a friend, but if you use excessive force you could be the one that is sued or 
become the criminal." (Student 5, FG1)

"You are becoming a care worker; you have to do loads for the victim. More and more is being put on the officer, re-contact and caring for people." (Student 12, FG1)

Other students, some of whom had experience as a Special Constable, explained how banter and humour were used to deal with specific members of the public.

"We had to strip search this homeless guy once (others laughing) and like the smell was indescribable (all laughing). When you come out the only thing to do is laugh as you are in disbelief that someone is like that and then you just end up having a laugh about it (all others laughing)." (Student 7, FG2)

Some did not agree with these views and this was seen particularly with students who did not go on to become Special Constables, with one stating. "I still class myself as a member of the public." (Student 11, FG3). In fact one student, who was also a Special Constable, also disagreed with the majority and stated,

"I have had generally good dealings with the public, I think it's because, say in [identified place], people are just passing through... generally I have had good dealings with them [the public]." (Student 7, FG3)

It was Focus group 4, who had spent most time on police patrol, where the "us and them" mentality became pronounced. Asked to describe their opinion of members of the public, a variety of pejorative terms were voiced. These ranged from extreme terms such as 'horrible' (Student 7, FG4) and 'scum bags' (Student 8, FG4) to one pathway student who said, "We did meet some lovely old people." (Student 2, FG4).

Finally, within this section, equality and diversity were issues that all of the students were aware of and commented upon. Many indicated they thought the police, as an organization, were too politically correct and had become too focused on what people could, or could not, say. This view was evident from those who became Special Constables as well as those who didn't.

"I think racism is said too much. If a white cop stops a black man he is racist. We all have that fear." (Student 2, FG2).

"If I wasn't 100\% that they had committed a crime I would be reluctant to stop them because they were an ethnic minority." (Student 1, FG1) 
Theme 3: Organizational culture and fitting in.

Participants who had witnessed Police work believed an occupational culture existed and this could vary between different police areas and teams. Some also described negative experiences associated with not fitting into their allocated police team. For some this meant questioning a future role in the Police, for two others (one male, one female) it meant resigning their position as a Special Constable. As one explained,

"There is one team that no Specials [Special Constables] can work with, it's like their team and no one is allowed in it. I have worked with them once and I am not doing it again. No matter what you do, they do not accept you. You do all of the brews [making cups of tea] and the paperwork for them and they just will not accept you." (S3, FG2)

In terms of general day to day cultural practice, one student gained consensus from other focus group participants when summing it up with the word, "Banter" (Student 10, FG2). Indeed, this ability to inject humour and light heartedness came over as a critical factor when immersing themselves in police work. Students said officers would joke about people's misfortune, using humour in a safe and confidential manner to deal with the challenges of the role.

"You just have to desensitise yourself..... when you are going to jobs, a lot of people think it's serious, but the amount of times people have done it, they just know what to do and it just comes like that, so they will quite often joke and that's what I enjoy, I enjoy the camaraderie of it." (Student 5, FG2).

Within the focus groups students often provided opinions on what the police should and should not be doing. A number of the students stated too much time was spent on 'social work' and more time should be spent on more deserving individuals, such as victims of crime.

"Yes, there are things we do that I just don't think we should, like looking for people who do not want to be found and I don't know er, I think people that like who take drugs and need looking after." (Student 4, FG4).

"It's not you cannot help them, they need to start helping themselves, before you can help them." (Student 4, FG4).

This role ambiguity and being engaged on specific work that some did not value had significant impact. It was commented upon throughout the focus groups.

"It's made me realise I don't want to be a bobby, erm, because I don't like shift patterns, and also there is so much time spent doing things in my opinion you shouldn't be spending time doing. Like going around and looking after people that don't deserve it, in my opinion." (Student 


\section{3, FG4).}

Further, for those who had (or were about to), join the Special Constabulary, there seemed a clear emphasis on valuing patrol and emergency response work, with only some pathway students indicating the importance of community work. Asked about their best experiences working alongside the police, a typical anecdote was provided below:

"Mine was when we were called to a job when a regular [serving Constable] needed assistance and we all went out to help and he had used a can of CS on him, got his baton out and us were the nearest to him. We managed to find him and if we had not got there he would have been in hospital, so we got there and sorted this lad out." (Student 13, FG4)

\section{DISCUSSION}

It is argued that police occupational culture has a negative influence on service delivery and reform. Enhanced training has been consistently highlighted (across continents, and time), as a way to reduce this influence and improve police professionalism. In more recent years, there has been an increased call to engage in Higher Education (HE), although these benefits have received little critical examination. The specific focus of this study was to examine the attitudes and behavior of students engaged upon a two-year full time Foundation Degree programme in Policing.

Two points should be made at the outset. First, future police officers emerge from many degree pathways and not just the Foundation Degree (which are traditionally designed to prepare individuals for a particular vocation). Secondly, this study had a particular emphasis on police culture, and should not be seen to reflect on the general performance or behavior of students. The students involved in this study received plaudits for their communication, confidence and team working skills. A police superintendent commented, "We've never had such a committed and enthusiastic bunch of individuals", which endorses the view that a University course can deliver benefits for the police service by providing students with key employment competencies. Roberg \& Bonn (2004), previously spoke of a positive chain reaction with HE leading to better communication skills. These in turn deliver better community policing, which generates greater police legitimacy, which ultimately leads to an increased likelihood of citizens obeying the law (Tyler 1990).

Several themes emerged in the study. The most striking was the speed with which students 
identified with the Police, which was seen to occur during the first week of university, or even before. Although $90 \%$ of FDP students initially reported wanting to mix with other students from other degree programmes, social isolation and in-group loyalty soon developed (Paoline, 2003). When speaking with the students the reason for this became obvious. These University students had enrolled on a specific degree course with a clear commitment towards a lifelong career path, which required them to embrace a particular lifestyle. Upon arriving at University this choice was no longer theoretical and their resolve was constantly tested with moral and ethical dilemmas. Facing examples of drug taking, drunken behavior, and inappropriate use of social media they were forced to make early decisions that isolated them from students on other courses. Commentators have argued police recruits do not come as a blank canvas - it also appears from this study that neither do police undergraduates who have not yet been recruited into the service.

Wood \& Tong (2009) exposed the contradictory status of student police officers. Heslop (2011) found that student police recruits suffered the double indignity of not being viewed as students or professionals. Further consideration needs to be given to this conundrum as it not only affects how students view themselves, but also how they can integrate in an academic setting. This vulnerability is amplified within FDP students, who find themselves betwixt and between not truly accepted as students but also not recruited (and therefore not fully accepted) as police officers. This process became more pronounced, over the two year programme, for those who became Special Constables. Further, it took place in a University setting, an environment which some thought could provide a mechanism to resist and tackle occupational culture. Rather than becoming more resistant, the students appeared to be become a more defensive, isolated and socially closed group.

This socialization process extended into many other areas, including how the FDP students viewed the public and perceived 'police work'. Although starting with an overwhelming desire to 'help the public', these attitudes became more negative, especially from those who became Special Constables. This was endorsed in the way they prioritized their mission to tackle crime and support each other, being intolerant of those who challenged their authority. This "us and them" divide, with members of the public, became more ingrained over time. Loftus (2009) pointed out that whilst a "reformed" police culture no longer deemed it acceptable to reveal overt racism or sexism, the stereotyping of the lower classes, such as unemployed males was accepted. This view appears to be supported in this study with both homeless people and drug users being singled out as targets for humour. It also supports the assertion that aspects of police culture can change and develop, as Chan (1996) suggested when she indicated individuals were not "cultural dopes". However, whilst occupational culture is powerful, individuals within the process are not passive, and further consideration is needed for individuals who resist its influence. This was evident in this research where a minority of 
students appearing confident in challenging negative attitudes.

Further, on this theme, Loftus (2009) found the new policies of diversity had resulted in a new aspect of culture, with white heterosexual males showing "resentment" to the pursuit of diversity. Whilst participants in the focus groups clearly highlighted the importance of diversity and emphasised that they would treat people without prejudice, many noted the "police had gone too far" and that as students they were concerned about dealing with someone from a different background to themselves, for fear of receiving a complaint. This again supports Loftus (2009) who argued attempts to eradicate racism has generated new aspects of culture and cynicism. It also highlights the constant challenge of promoting diversity, not just with a focus of minority ethnic citizens, but also the most vulnerable including the unemployed and drug users.

Turning to the lecturers and their influence, some commentators (Shearing and Ericson, 1991; Chan, 1996) believe 'stories and myths', passed by experienced officers to novice recruits, are critical to understanding police craft and transmitting cultural knowledge. This study shows this process can also take place in a university setting. Many of the student participants viewed the lecturer's credibility stemming not from their academic achievements but from their stories, police service and rank. Can this cultural influence be combatted by using 'pure academics' with no previous Police association? Heslop (2011) highlights this approach brings its own unintended consequences, with police students feeling isolated, with academic staff ignoring legitimate operational experience. As such, whilst the ideal staff profile may prove elusive, whoever educates police students should challenge the negative aspects of organizational culture, whilst simultaneously respecting operational demands.

In summary, this research indicates that negative aspects of police culture can be developed even within a university setting, through police association and placement training. This article does not advocate that such programmes are of little use as they appear (anecdotally) to improve a student's knowledge and social skills in ways police training would be unable to do. However, the study does challenge the suggestion that just because prospective police officers avail themselves of H.E., wider benefits will automatically follow. Researchers have previously argued that higher educated police officers could bring benefits in terms of less authoritarianism (Smith et al. 1970; Guller, 1972), less prejudice, better performance (Rodano, 1978) and more flexibility (Trojanowicz \& Nicholson,1976). Further, Wood (1997: 276) argued that: "Recruits have an exposure to the external influence of an open campus ....thereby limiting potential for entrenchment of the negative culture which might be encouraged if their entire training was conducted in a closed and isolated residential college." However, this study shows that purposely designed Foundation degrees can intensify the bond within the student cohort, who are more likely to identify with a Police organizational culture. As such this, and 
other tailored policing degrees, should be wary of not appearing as enhanced police training in a different environment. Careful consideration should be given to the design of any police related degree. This needs to embody the strengths of $\mathrm{HE}$, including critical and reflective analysis and allowing police students to mix and listen to other viewpoints. It should also provide students with multi-disciplinary perspectives (e.g. Criminology, Psychology and Sociology), to increase empathy and understanding. Finally, the ramifications of organizational culture should be identified and tackled in an explicit way.

\section{CONCLUSION}

For community trust to flourish the police service needs officers who are unbiased, trustworthy and able to interpret situations and people without invoking prejudice. Higher Education can bring numerous benefits when developing future recruits within this vision. However this study shows the association of these University students with the Police changed both the way they viewed themselves, and the way in which they were perceived by others.

This suggests that the pathway to changing police culture is not simply through moving the police training site to a university campus, even when the students are not yet employed as police officers. Neither does this research advocate that such programmes should be stopped as it is clear the student picks up many competencies that improves their operational competence. However, this research indicates that the occupational culture is so strong within policing that it needs to be considered within the structure of training and education of higher education programmes. Specifically, more consideration is needed to increase student resilience to police culture at this pre-recruitment phase and throughout their career.

\section{REFERENCES}

Alcott, C. (2012) Reforming the force: An Examination of the impact of the operational subculture on reform and modernisation within the police service. British Journal of Community Justice, vol. 10, (no.1), 5-14.

Banton, M. (1964) The Policeman in the community. London: Tavistock.

Blakemore, B. \& Simpson, K. (2010) A comparison of the Effectiveness of Pre-and PostEmployment Modes of Higher Education for Student Police Officers. Police Journal, vol.83 (1), 29-41.

Blain, M. (2009) No degree PC plods should be Bobby (BA). Police Review, 20-11, 5. 
Butler, A. J. P. \& Cochrane, R. (1977) An examination of some elements of the personality of police officers and their implications. Journal of Police Science and Administration, vol. 5 (3), 441-450.

Calvert-Smith, D. (2005) The police Service in England and Wales: Final report of a formal investigation by the Commission for Racial Equality. London: Commission of Race Equality. Cashmore, E. (2002) Behind the window dressing: ethnic minority police perspectives on cultural diversity. Journal of Ethnic and Migration Studies, vol. 28 (2) 327-341.

Chan, J. (1996) Changing Police Culture. British Journal of Criminology, vol. 36 (1), 109-134. Chan, J. (2001) Negotiating the field: New Observations on the Making of police officers. The Australian and New Zealand Journal of Criminology, vol. 34 (2), 114-133.

Christie, G., Petrie, S., \& Timmins, P. (1996) The Effect of Police Education, Training and Socialisation on Conservative Attitudes. Australian and New Zealand, Journal of Criminology, vol. 29 (3), 299-314.

Cockcroft, T. (2015) Golden Ages, Red Herrings and Post-Keynesian Policing. Norkisk.

College of Policing (2016), http://www.college.police.uk/About/Governance/Documents/BoardMinutes/June_2016_Boar d_Minutes.pdf.

Colman, A.M. \& Gorman, P.L. (1982) 'Conservatism, dogmatism, and authoritarianism in police officers', Sociology, 16, 1-11.

Conlon, E. (2004) Blue Blood. New York: Penguin.

Crank, J. P. (1990) Police: Professionals or Craftsmen? An Empirical Assessment of Professionalism and Craftsmanship amongst eight Municipal Police Agencies. Journal of Criminal Justice, vol.18, 33-349.

Dalley, A. F. (1975) University vs. Non-University graduated policeman: a study of police attitudes. Journal of Police Science and Administration, 3, 458-468.

Dominey, J. \& Hill, A. (2010) The Higher Education Contribution to Police and Probation Training: Essential, Desirable or an Indulgence? The British Journal of Community Justice, 8 (2), 5-16.

Emsley, C. (2008) The Birth and Development of the Police, in Newburn, T. (ed) (2008) Handbook of Policing (2nd ed). London: Willan Publishing Fekjaer, S.B. (2014), Police students' social background, attitudes and career plans, Policing: An International Journal of Police Strategies \& Management, 37(3), 467-483.

Fielding, N. (2002) Cop canteen culture. In T. Newburn \& E. Stanko (eds.) Just boys doing business. London: Routledge, 46-63.

Frevel, B. (2015), Pluralisation of local policing in Germany, European Journal of Policing Studies, 2(3), 267-285.

Graef, R. (2012) Why the lessons of Lawrence are still being learnt by the Met? The Times, $4^{\text {th }}$ January.

Guller, I., B. (1972) Higher education and policemen: Attitudinal differences between freshman and senior police college students. The Journal of Criminal Law, Criminology, and Police Science, 63, 396-401.

Hallenberg, K. M. (2012) Scholarly Detective: Police Professionalization via academic education. Thesis (PhD), University of Manchester. 
Heath, L. (2011) Preparing new police officers for their careers: in-house training or university education? Widening Participation and Lifelong learning, 12(2), 105-123.

Heslop, R. (2011), Reproducing police culture in a British university: findings from an exploratory case study of police foundation degrees, Police Practice and Research, 12(4), 298312.

Home Office (1999) Home Office, Dismantling the barriers to reflect the community we servethe recruitment, retention and progression of Ethnic Minority Officers. London: Home Office. Jaschke, H. G. \& Neidhardt, K. (2007) A Modern Police Science as an Integrated Academic Discipline: A Contribution to the debate on its Fundamentals. Policing and Society, vol.17 (4), 303-320.

Kiely, J. A. \& Peek, G. S. (2002) The culture of the British police: views of police officers. The Service Industries Journal, vol. 22 (1), 167-183.

Loftus, B. (2008) Dominant culture interrupted. British Journal of Criminology, 48, 756-777. Loftus, B. (2009) Police Culture in a Changing World. Oxford: Oxford University Press.

Maghan, J. (1988) The 21st century cop: police recruit and perceptions as a function of occupational socialization. New York: The City University.

Martins, E.C. \& Terblanche, F. (2003) Building organizational culture that stimulates creativity and innovation. European Journal of Innovation Management, vol. 6 (1), 64-74.

McLaughlin, E. (2007) The New Policing, 2nd ed. London: Sage.

Moeberg, R.J., \& Pettersson, O. (2016), Different educations - different police recruits? Paper presented at the European Conference of Criminology, 22.9.16

Neyroud, P. (2011) Review of Police Leadership and Training. London: Home Office. Paoline, E. (2003) Taking Stock: Toward a richer understanding of Police culture. Journal of Criminal Justice, vol. 31 (3) 199-214.

Punch, M. (1979) Policing the inner city. London: Macmillan.

Recpol (2016) Recruitment, Education and Careers in the Police: A European Longitudinal Study is a survey of police recruits. The survey follows the recruits through their education and into their professional careers. http://www.phs.no/en/research/forskningsomrader/politietsorganisasjon-kultur-og-adferd/recpol/ viewed 26.1.17

Reiner, R. (2000) The Politics of the Police 3rd Edn. Oxford: OUP.

Reith, C. (1956) A New Study of Police History. Great Britain: Cunningham and Sons Roberg, R. \& Bonn, S. (2004) Higher education and policing: where are we now? Policing: An International Journal of Police Strategies \& Management, vol. 27 (4), 469 - 486.

Sarantakos, S. (2005). Social research (3rd ed.) Hampshire, UK: Palgrave Macmillan. Shearing, C. \& Ericson, R. V. (1991) Culture as figurative action. British Journal of Sociology, 42 (4), 481-506.

Skolnick, J. H. (1966) Justice without Trial: Law Enforcement in Democratic Society. New York: Macmillan. 
Smith, A. B., Locke, B., \& Fenster, A. (1970) Authoritarianism in policemen who are college graduates and non-college police. Journal of Criminal Law, Criminology, and Police Science, 61, 313-16.

Stradling, S.C, \& Harper, K. (1988) The tutor constable attachment, the management of encounter and the development of discretionary judgement. In Southgate, P. New directions in police training, London, HMSO.

Terrill, W., Paoline, E. A, Manning, P.K. (2003) Police culture and coercion. Criminology, 41 (4), 1003-1034.

Tilley, N. \& Laycock, G. (2016), Engineering a Safer Society, Australian Institute of Police Management, 4(2), 1-6.

Trojanowicz, R.C. \& Nicholson, T. (1976) A comparison of behavioural styles of college graduate police officers v. non-college going police officers. The Police Chief, 43, 57-8.

Twersky-Glasner, A. (2005) Police Personality: What is that? And why are they like that? Journal of Police and Criminal Psychology, 20, 56-67.

Tyler, T. (1990) Why people obey the Law? London: Yale University Press.

Tyler, T. (2004) Enhancing police legitimacy. Annal, AAPS (no.539,) 84-99.

Van Maanen, J. (1975) Police Socialisation: A Longitudinal Examination of Job Attitudes in an Urban Police Dept. Administration Science Quarterly, 20 (2), 207-228.

Van Maanen, J. (1976) Rookie cops and rookie managers. The Wharton Quarterly, 1(1), 49-55. Van Maanen, J. (1978) The asshole. In P.K. Manning and J. Van Maanen (eds.) Policing: A View from the Streets. New York: Random House.

Waddington, P. A. J. (1999) Police (canteen) sub-culture: an appreciation. British Journal of Criminology, vol. 39 (2), 287-309.

Wilson J, Q. (1968) Varieties of Police Behaviour. Cambridge: Harvard University Press.

Winsor, T. (2011) Winsor report; Part 1 and Part 2. London: Home Office.

Winsor, T. (2012) Police officers don't have to have blue collars. The Times, 16th March. Wood, D. A. \& Tong, S. (2009) The future of initial police training: a university perspective. International Journal of Police Science and Management, vol.11 (3), 294-305.

Wood, J. Commissioner (1997) Royal Commission into the New South Wales Police Service. Sydney Government.

Worden, R. E. (1990) A badge and a baccalaureate: policies, hypotheses, and further evidence. Justice quarterly, 7, 565-92.

**This is an article which has been accepted for publication in 'Policing: An International Journal' 